\title{
$x$ ニエール病難症例の検討
}

\author{
宮田英 雄・安田ゆかり \\ 伊藤八次・伊藤敬子
}

\section{はじめに}

メニェール病は病像や重症度に個人差や経過の変動が 大きい。1 2 回の軽いめまい発作で, 蝸牛症状も回復 し長い期間発作の起こらない例があるが，一方社会生活 に著しい支障をきたす重症例（難症例）も存在する。

昭和 52 年に厚生省特定疾患調査研究メニエール病疫学

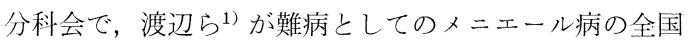
調査報告を行っている。それから11年が過ぎ，その実態 がどのよらな傾向になっているかを把握するために検討 を始めた。そして，本疾患の今後の治療と予防対策の資 料の一つにしたいと考光ている。今回はPreliminaryな 報告である。

\section{方法}

(1) 対象

昭和 62 年 7 月から 63 年 9 月末でに岐阜大学耳鼻科を受 診し, 岐皁大学のメニエール病診断基準2)でメニエール 病確実と診断した41名（男21名，女20名）である。年齢 は最低14歳，最高76歳であった。

(2) 検討事項

(1)メニエール 病難症例の 分類を渡辺ら ${ }^{1)}$ の基準（表 1) を用いて, 当科初診時の病歴と検查成績から行っ た。同一症例で，複数の型に該当するときにはそれぞれ の型に重複してとり入れた。男女別の合計例数は重複を 差引いた実例数とした。(2)メニエール病難症例は難症例

表 1 メニエール病難症例の分類 ${ }^{1}$

$\mathrm{A}$ 型：め亦発作が 3 カ月以上にわたって，平均月 1 回 以上反復しているもの。

B型：めまい発作後のぐらつき，ふらふら感が持続し,

3 力月以上仕事や学業が手につかないもの。

C型：片耳の難聴が高度（ろらに近い）となったもの。

$\mathrm{D}$ 型：両耳の難聴が高度でろらに近くなったもの。

$\mathrm{E}$ 型：その他，社会生活に重大な支障を来した例。

†Study on Severe Cases of Meniers's Disease

Hideo Miyata, Yukari Yasuda, Yatsuji Ito and

Keiko Ito

岐皁大学医学部耳鼻咽喉科学教室
でない例と 差違があるかを検討するために，1）経過 (めまい発作の初発から当科初診日までのめまいの罹病 期間)，2）聴力検査成績（4 分法平均聴力レベル), 3 ）蝸電図・グリセロールテスト成績，4）温度検查成 績（Hallpike 法，持続時間で判定した CP％) を比較し た。

\section{結 果}

(1) $x= \pm ー ル$ 病難症例の分類

難症例の型別, 性別, メニエール病確実例全体に対す る比率を表 2 に示した。難症例はメ二エール病確実例 41 名中11名 (26.8\%) で，性別は男 7 名 (33.3\%), 女 4 名 (20\%) であった。型別はA型（めまい発作頻発）が 男女合わせて10名 (24.4\%), B型（発作後のめまい感） とC型（片側ろら）が各々 1 名 $(2.4 \%), \mathrm{D}$ 型（両側ろ ら） 0 名， $\mathrm{E}$ 型（その他重大な支障を示す）が 3 名(7.3

表 $2 x=エ ー ル$ 病難症例の型別性別

\begin{tabular}{|c|c|c|c|c|}
\hline 型 & 男 & & 女 & 計 \\
\hline $\mathrm{A}$ & $6 / 21(28.6 \%)$ & $4 / 20$ & $(20.0 \%)$ & $10 / 41(24.4 \%)$ \\
\hline B & $1 / 21(4.8)$ & $0 / 20$ & & $1 / 41(2.4)$ \\
\hline $\mathrm{C}$ & $1 / 21(4.8)$ & $0 / 20$ & & $1 / 41(2.4)$ \\
\hline $\mathrm{D}$ & $0 / 21$ & $0 / 20$ & & $0 / 41$ \\
\hline $\mathrm{E}$ & $3 / 21 \quad(14.3)$ & $0 / 20$ & & $3 / 41 \quad(7.3)$ \\
\hline $\mathrm{A} \sim \mathrm{E}$ & $7 / 21 \quad(33.3)$ & $4 / 20$ & $(20.0)$ & $11 / 41 \quad(26.8)$ \\
\hline
\end{tabular}

表 3 経過（初発から初診日までのめまいの罹病期間）

\begin{tabular}{l|c|c}
\hline & 難症例 (11名) & 難症例でない例(30名) \\
\hline \begin{tabular}{l|l} 
年 \\
$1 \sim 2$
\end{tabular} & 2 & 3 \\
$2 \sim 5$ & 2 & 6 \\
$5 \sim 10$ & 4 & 4 \\
$10 \sim 15$ & 1 & 8 \\
$15 \sim 20$ & 1 & 2 \\
$20 \sim 25$ & 1 & 4 \\
$25 \sim 30$ & & 1 \\
$30 \sim$ & & 2 \\
\hline
\end{tabular}




\section{良 聴耳}



表 4 蝸電図・グリセロールテスト成績

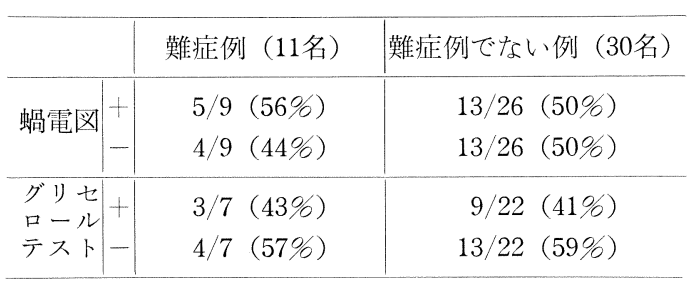

表 5 温度検查成績

\begin{tabular}{c|c|c}
\hline $\mathrm{CP}(\%)$ & 難症例 (11名) & 難症例でない例(30名) \\
\hline $0 \sim 19$ & 4 & 19 \\
$20 \sim 40$ & 5 & 6 \\
$41 \sim 60$ & 1 & \\
$61 \sim 100$ & 1 & 3 \\
未施行 & & 2 \\
\hline
\end{tabular}

\%)であった。各型ともに表 2 に示すよらに男性が多い 傾向であった。

(2) 難症例と難症例でない例との比較

1 ）経過: 結果を表 3 に示した。難症例は 1 年末満は なかった。難症例でない例でも 30 年以上（30年 3 力月と 32年）が 2 名あった。

2 ）聴力検査成績 : 難聴の程度を悪聴耳と良聴耳との 関連で図 1 に示した。悪聴耳 $40 \mathrm{~dB}$ 未満であるのが難 症例 4 名 (36\%)，難症例でない例 17名（57\%）であっ た。 $40 \mathrm{~dB}$ 以上を示したのが難症例 7 名 $(64 \%)$, 難症例
でない例13名（43\%）であった。すなわち，難症例の悪 聴耳は $40 \mathrm{~dB}$ 以上の聴力レベルを示すものが多かった。

3 ）蝸電図・グリ七ロールテスト成績 : 結果を表 4 に 示した。蝸電図検査で陽性を示したのは，難症例は56 $\%$ ，難症例でない例は $50 \%$ であった。グリセロールテス 卜陽性例は難症例 $43 \%$ ，難症例でない例 $41 \%$ であった。 臨床的に内リンパ水腫の存在を推定する検査成績は, 両 者にほとんど差がみられなかった。

4 ）温度検査成績 : 結果を表 5 に示した。CP 20\%以 上を示したのが難症例 7 名 $(63.6 \%)$ ，難症例でない例 9 名 $(32.1 \%)$ であった。

\section{考案}

メニエール病難症例は今回の成績ではメニエール病確 実例の $26.8 \%$ であった。昭和52年の渡辺ら ${ }^{1)}$ の調査では $54.7 \%$ でった。この差は今回は当科単独での検討で対 象が少なかったことによると思われる。

次に難症例の内容をみると, A型のめまい発作の反復 に悩んでいる例が多く, 次いで $\mathrm{E}$ 型のその他重大な支障 をきたしている例であった。この両型共に男性が多かっ た。渡辺ら ${ }^{1)}$ の成績も A 型が多く，男性に多かった。メ ニエール病患者はめまい発作の反復に一番悩んでいるこ とに特徵がある。渡辺ら ${ }^{1)}$ は戦後メニエール病例が増加 し，女性の方が男性と同数かむしろやや多くなっている が，難症例は男性の比率が高いことは注目に值すると述 ベている。そして時代と共に変化するものであるか興味 ある課題としているが，渡辺ら ${ }^{1)}$ の調查より11年を過ぎ た今回の当科だけの成績も男性が多い傾向は変りなかっ 
た。この要因を今後検討する必要がある。

難症例は難症例でない例と相違があるかを，めまいの 経過, 難聴の程度, 蝸電図・グリセロールテスト成績, 温度検査成績を比較検討した。めまいの経過は難症例で は 1 年未満はなかった。聴力は難症例の悪聴耳は $40 \mathrm{~dB}$ 以上の聴力レベルを示すものが多かった。温度反応は難 症例は CP 20\%以上を示すのが多かった。難症例は障害 程度が強い例が多い傾向が久られた。

蝸電困・グリセロールテスト成績は両者に大きな違い はみられなかった。

難症例の検討は，今後更に対象，検討項目を増やして 行う必要があると考えている。

\section{まとめ}

重症メニエール病（難症例）の実態を渡辺らの基準を 用いて検討した。社会生活に支障をきたしている難症例 はメニエール病確実例 41名中 11名 $(26.8 \%)$ で, 男 7 名，女4名であった。そのうちめまい発作頻発に悩杂例 が多かった。

難症例と難症例でない例を比較すると，難症例は 40 $\mathrm{dB}$ 以上の聴力レベル， CP 20\%以上を示すのが多かっ た。螖電図・グリセロールテスト成績は両者にほとんど 差がなかった。

\section{謝辞}

本研究は厚生省特定疾患前庭機能異常調査研究班の研 究費援助により行われたものである。

\section{文献}

1) 渡辺 勈, 中江公裕, 大久保 仁, 水越鉄理 : 難病 としてのメニエール病の全国実態調查報告. 厚生省 特定疾患 $メ$ ニール病調查研究班 昭和 52 年度研究 報告書並びに研究業績集 29-36, 1978

2 ) 時田 喬, 宮田英雄, 牧 達夫, 斉藤富康, 橋本正 彦：メニエール病の臨床. 耳鼻臨床 $73: 885-897$, 1980

\section{Abstract}

We investigated severe cases of Meniere's disease. The diagnosis was based on the criteria of diagnosis of severe cases of Meniere's disease by Watanabe (1978). Severe cases existed in 11 (7 males and 4 females) of 41 patients with Meniere's disease. In 10 of these cases, attacks of vertigo occured above once a month on an average for more than 3 months. In addition, their hearing level was more than $40 \mathrm{~dB}$ and they had $20 \%$ canal paresis. However, there was no significant difference in the results of electrocochleography and glycerol test between patients with and without severe cases.

Key words : Meniere's disease, severe casese

$$
\left(\begin{array}{l}
\text { 原稿到着: 平成 } 1 \text { 年 } 7 \text { 月 } 10 \text { 日 } \\
\text { 別刷請求先 : 宮田英雄 } \\
\text { T500 岐阜市司町 } 40 \\
\text { 岐皁大学医学部耳鼻咽喉科学教室 }
\end{array}\right)
$$

